\title{
The Humour in My Tumour: Respecting Legal Capacity in Health- Care Decision-Making
}

Roxanne Mykitiuk

Osgoode Hall Law School of York University, rmykitiuk@osgoode.yorku.ca

Reshma Valliappan

Source Publication:

Eilionoir Flynn, Ann Arstein-Kerslake, Cliona de Bhalis \& Maria Laura Serra (eds.). Global

Perspectives on Legal Capacity Reform: Our Voices, Our Stories, London: Routledge (2019).

Follow this and additional works at: https://digitalcommons.osgoode.yorku.ca/scholarly_works

Part of the Health Law and Policy Commons

\section{Repository Citation}

Mykitiuk, Roxanne and Valliappan, Reshma, "The Humour in My Tumour: Respecting Legal Capacity in Health-Care Decision-Making" (2019). Articles \& Book Chapters. 2720.

https://digitalcommons.osgoode.yorku.ca/scholarly_works/2720

This Book Chapter is brought to you for free and open access by the Faculty Scholarship at Osgoode Digital Commons. It has been accepted for inclusion in Articles \& Book Chapters by an authorized administrator of Osgoode Digital Commons. 
Figure 1 
The Humour in my Tumour: Respecting Legal Capacity in Health Care Decision Making

Reshma Valliappan \& Roxanne Mykitiuk

The Irreversible Madness - 2011

Figure 2 
Figure 3

\section{Suffering Smothering System - 2013}

A year and a half after my craniotomy, my seizures were still not under control by the medications prescribed. It was $23^{\text {rd }}$ June 2011 when I had to undergo a surgery for the removal of a meningioma which was growing over the left hemisphere of my brain. The surgery could not be delayed as the tumour had begun affecting my body physically and delay in its removal could lead to irreversible brain damage. The prognosis given to me was that I needed a full year of being seizure free before the medications could be reduced. My diet, lifestyle, work, social, emotional, mental, physical, spiritual life got overturned by the invasion of a few little buggers by the name of Levera and Gabapentin ${ }^{1}$. I was worse off than before. 
Everything became over stimulated. The surgeon said it was a side effect of the surgery which in itself is a trauma for the brain to have the skull opened up. Added to the removal of a creature sitting on top of my brain and pressing it down for years (since they couldn't tell how long the tumour was growing on top of my left hemisphere). It appeared that the tumour had made its home on my brain and now its removal was like forcing an abusive lover to leave its home. And like most abusive lovers who come back, there was no certainty it would not return, though after six years it has not been back.

A physician, Dr. X, explained that after my surgery, my wonderful crazy brain showed scar tissue. It was natural that it would, and that the scar tissue would have memories of the tumour. This in turn would affect what the brain would remember, which means even if there is no tumour the brain could think the tumour is still there and go on experiencing seizures.

Dr. X said I have to keep taking these medications and I can't stop them as I did with my meds for schizophrenia giving the same prognosis: 'Until you are free from seizures for an entire year, only then can there be a reduction of the meds which again have to be monitored as just one seizure in itself means another relapse to work with'.

"But that means meds for life", I said. "Cause everything can cause a seizure including working on my laptop, indigestion, chocolates, working out, dehydration, anger, heat, dance floors, martial arts, tai chi, alcohol, dancing, hopping, lights, cinemas, Xbox, television, music, pranayama ${ }^{2}$... am I supposed to not breathe at all then? If I can't do everything in life, then what's the point in having one?"

He looked at me with no certainty to my question but said "Well, you'll have to figure it out then and work with your neurologist" ${ }_{-}$.

It was very distressing that I had to live with this new brain problem now. Mr. Scar Epilepsy wasn't really a nice guy. I thought my life was really over and no one could understand why I was reacting the way I did. It was very easy for them to say take it in your stride, you've already gone through other stuff in life...this should be easy. It was very easy for them to have a list of expectations, questioning my strength during adversity ${ }_{2}$ since I was quite a goof all the time and saw humour in everything. But at that point in my life, I was trying to come to terms with the ever strange brain problems with which my life was presented, and the walk 
was a very lonely one ${ }_{2}$ as the disabling nature of it is never visible to others...I began withdrawing more from everyone.

I had messaged my neurologist late evening on a Saturday. I asked what would happen if someone consumed all the frisiums ${ }^{4}$, anti-anxieties and anti-epileptics with alcohol. My neurologist messaged back, but I passed out trying to read the message and woke up in a very strange place with my limbs tied up, an extension wire sticking out of my hand, and everything was white (well that's what it looked like. I thought the aliens attached me to some device and were transferring their consciousness through my arms).

As I opened my eyes and made some gibberish sounds, my mother walked up and placed her hand on mine "Reshma, can you hear me?" I looked at her with acknowledgement and asked her what happened. Why was she looking so sad? I had some memory of something but I don't know what that something was and what that memory was. Mom said "You tried taking your life Reshma."

I heard that and fell asleep again only to awaken later with nurses all around me and the doctor having a conversation with my mom and dad. I woke up again but I sounded different. I asked for something but my mother couldn't understand what I was saying.

I threw a fit demanding that I get out of that place. My folks said I couldn't $t_{2}$ as I have to be in hospital. Mom calmed me down and tried narrating to me the details of what had transpired. "You took all your pills Resh and we had to rush you to the hospital. Then you also bit your sister on her hand and she cried because she was surprised you would do that. The mamas (hospital ward men) ... 5 of them had to hold you down because you refused to calm down. The doctor was finding it difficult because you were being very violent so they had to tie you down to the bed but even then you managed...” and poof! I fell asleep again.

I kept going in and out of consciousness those few days until a sedative was given, only then would I remain asleep for long hours. I woke up again and looked around me. I was still lying on bed with my legs tied but arms loose. My mom narrated what happened.

"Resh, you had taken the rod that was holding your drip and sat on your bed moving it around and hitting everything. None of us were there as we went home because we were told you were fast asleep. Thankfully, the evening nurse was just signing out but upon hearing the commotion she rushed in to your room. She sat with you for an hour at least and waited for 
me to come back. She told the other nurses to leave as she knew they would react in fear and wouldn't understand, so she decided to wait until you calmed down."

"Who was she mom, did you ask for her name?" I enquired.

"No, I was so shocked and confused so I just thanked her and forgot to ask for her details" mom said.

"But she was like an angel sent for you Resh. If she wasn't around then the hospital would again trouble us and involve the police."

I do recollect the nurse holding my palm and standing very close to my bed to avoid being hit by the rod since I was still holding it. That was a smart thing she did since the rod, being long, wouldn't have been able to hit her as she was so close to me. She managed to talk me through the reasons I was swinging the rod and establish communication with me. After this she asked if I could give her the rod since my saline drip was all over the floor and that would complicate things for me. I knew she was telling me the truth as I was feeling giddy, exhausted and thirsty, and even if it wasn't the truth, my body was not able to hold on to the rod or to sit up any longer.

So I gave her the rod. She called in a nurse to replace my drip and clean the place while holding my palm and talking to me. Then she fed me some water and said they will need to put in a sedative as they might be afraid that I'll end up hurting myself or others again. She asked me if she can do it herself and continued "Trust me okay. This will help you rest a little as you have exhausted yourself so much with the swinging. I'll wait with you until your family members come in." I said yes and by the time I was looking for more words I had already passed out.

My ex-psychiatrist was worried as to why I pulled such a stunt and got violent throughout my admission. My first counsellor who was just driving through that locality had received a message from my mother and decided to drop in to visit me. Mom said, "Resh, your counsellor looked very worried and didn't know what or how to help you."

The unknown nurse who took responsibility at such a moment to care and stand by me speaks for all other 'strangers' in the world who, when given the power of care, will do something about it. We've always thought about care being a job of the treating doctor and other white coats who check you out and give you a prescription... unfortunately or fortunately. But I see care as a full circle existing within a community and there are many different players in a 
community. Most certainly these players would not be able to play their roles if their lives and capacity to make decisions were controlled by another authority. But when there is no second or third authority in the room they pretty much can choose to care for you with kindness and compassion and enable you to still feel you are capable of choice. How else can we translate or show care towards a mind that is running amok?

My experience after this attempt was followed with more 'unique' experiences of violence to self. A visiting psychiatrist watched me get a seizure in front of her. When it was over, she stood and chatted with me and then told my mom "This isn't a symptom of schizophrenia. I'm seeing with my own eyes how painful the seizure is for her and she is able to communicate to me."

When she said that, I was so grateful my mom heard it from her and told my dad too. But, I had been saying the same thing for some time and no one believed me, including my treating neurologist. I could only be believed when another doctor said the same thing. So evidently, my sanity does rely on another authority.

It is easy to wipe the wounds and clean the blood of an injured arm and gently blow on to a wound so that it doesn't burn and hug the person to make them feel secure and safe, and even sing them lullabies as they sleep. But this method might not be possible for someone who does not like touch to begin with and has too many thoughts about the world around her and speaks a very different language. Care, choice and capacity are spoken about in the English language and this is very limiting because English is a language and not the measure of compassion, communication or of intelligence.

I always ask others to learn some autism, some schizophrenia, some depression, or some seizures and then communicate to me and others in those languages and see if they can do it. And if they can't, then they can't place such linguistic expectations on us to be in a position to communicate ourselves. Even MBA students have to enroll in workshops and classes to learn about 'Communication' but nobody questions their capacity to make decisions if they are unable to communicate and deliver a presentation at a board meeting. What is this communication that the mental health sector is referring to? And how is that determining my ability to choose for my care? 
Care as many of us know of it does not exist in 'Mental Health Care'. This term itself implies that you are caring only for the state of the person's mentality and not for the person as an entity in their own right.

Reshma's story illustrates the discriminatory and prejudicial health care services and treatment that persons regarded as lacking capacity are subject to as they navigate a health care system that is more intent on reinforcing dynamics of power than listening and attending to the health needs of the person with a disability. Yet, while her narrative is cautionary and critical, it is also instructive and hopeful.

Reshma's narrative, while grounded on Article 12 of the Convention on the Rights of Persons with Disabilities (CRPD) which recognises the right to legal capacity on an equal basis with others without discrimination on the basis of disability, also engage those of Article 25 and the relationship between the two._Article 25 of the CRPD provides a fundamental right for persons with disabilities to the highest attainable standards of health without discrimination on the basis of disability and therefore, the right to seek medical care and receive it on an equal basis with others. Reshma sought treatment for physical symptoms that were causing her significant distress and were subsequently determined to be caused by a brain tumour. However, Reshma was denied basic medical care and her novel physical symptoms were immediately attributed to her schizophrenia without apparent further investigation. This failure to investigate and treat constitutes discrimination on the basis of her disability and is a violation of her human rights as protected by Articles 12 and 25 of the CRPD as demonstrated below 5 .

Article 12 CRPD guarantees persons with disabilities the right to equal recognition before the law and the right to enjoy legal capacity on an equal basis with others in all aspects of life. It is the right to have one's decisions legally recognised. Reshma's decision not to take medication prescribed for schizophrenia was not accepted and respected by the physician. Instead, the physician implied that Reshma would be denied any further medical care for her current symptoms until she complied with a pharmaceutical-based treatment course for her psychiatric condition. Thus, Reshma would have had to take drugs against her will and preferences, to access standard medical care. In addition, by not respecting her legal capacity regarding Reshma's decision not to take drugs for her schizophrenia, the physician further 
discriminated against Reshma in regards to other aspects of her health, including investigation of a new set of symptoms and signs that ultimately should have led to an earlier diagnosis and treatment of Reshma's brain tumour and thus less pain, anguish and complications for her.

After Reshma's surgery for a brain tumour, which was delayed because the doctors attributed her report of new symptoms to her schizophrenia and her refusal to take medications for its treatment, one of the subsequent complications of the surgery was seizures. Even when it should have been clear to Reshma's physicians that not respecting her will and preferences in decision making regarding taking medications for schizophrenia led to a delay in the diagnosis of her brain tumour, Reshma's self determination in health care decision making was again denied when she developed the surgical complication of seizures and she was hesitant to take drugs for this potential complication of the late diagnosis. Reshma was provided only one option for treatment - medication for her seizures. She made clear expressions of her desire for another treatment route and expressed significant concerns about the only treatment option that was offered and the implications this would have for her quality of life.

Within a framework for consent that complies with international human rights standards including Article 12(1) of the International Covenant on Economic, Social and Cultural Rights (1966), the Convention on the Elimination of All Forms of Discrimination against Women (1979), the Convention on the Rights of the Child (1989) and the CRPD (2006), Flynn and Brosnan (2017) propose several essential elements that must be present for valid consent to be ascertained. These elements include the recognition of legal capacity, freedom to negotiate, provision of information, respect for will and preference and voluntariness (Flynn_and Brosnan, 2017). The authors state that there is an obligation on the individual proposing to act upon the body of another to ensure that this person has all the relevant information about the action to which she is being asked to consent (Flynn and Brosnan, 2017). As argued by Morrison et al. (2012), in the medical context, the provision of sufficient information would require the treating mental health professional to disclose all possible side effects of the proposed medication or treatment procedure, in a manner accessible to the person.

An important objective in the process of obtaining consent is the elimination of conditions that would vitiate valid consent, which include the threat of coercion or force on the decision. 
This concern is especially relevant in the context of consent to medical treatment, where an inherent power imbalance exists between patient and physician. Gaventa describes three forms of power that exist in relation to decision-making in the medical treatment context: visible, hidden, and invisible (Gaventa, 2006). Commentators have discussed how through 'hidden power', medical professionals can control the agenda and influence what information is brought to the decision-making table when treatment decisions are being made (Flynn and Brosnan, 2017). Indeed, some physicians may choose to withhold information on potential side effects of medications, in order to ignore that the patient could cope without medication (Flynn and Brosnan, 2017).

As Reshma tells us in her story, she was not fully informed of the side effects of the antiepileptic medication she was prescribed for her seizures, the benefits of taking such medication or what the possible effects of not taking the medication would be. Given Reshma's clearly stated (and acted upon) preferences regarding the use of anti-psychotics, coupled with her articulated concerns about the implications of taking anti-seizure medications on her quality of life, the physician's response to Reshma's concerns about the anti-epileptic medication that 'well, you'll have to figure it out then (emphasis added) and work with your neurologist,' appears to undermine Reshma's ability to make informed choices because her physician is not prepared to discuss treatment options nor to engage in a discussion of the consequences of not taking anti-epileptics. Rather than exploring the negative side-effects and consequences of taking anti-epileptics, the possible alternatives to anti-epileptics or the consequences of a choice not to take them with Reshma, her physician ignored the requirements for valid consent, asserting his power, and ignoring Reshma's expressed preferences.

Not all of Reshma's encounters with healthcare providers were negative. In her story, the respect afforded her by one of her nurses, following her suicide attempt, illustrates a course of action that adheres to the mandates of Article 12 of the CRPD. In this instance, the nurse respected and affirmed Reshma's legal capacity, rather than disputing it, and worked with her, creating the conditions of support, respect and trust in which Reshma was able to communicate her consent and make decisions about her own life. Article 12(3) of the CRPD creates the obligation for States to provide support for the exercise of legal capacity, as opposed to permitting State actors to discriminatorily intervene in the lives of persons with disabilities. This nurse's interaction with Reshma provides evidence that practices involving respectful communication and trust can be used as alternatives to forced medication of 
individuals experiencing emotional distress. Open dialogue is one communication-based approach that involves the individual experiencing psychosocial crisis, their friends and family members, and mental health professionals in a partnership approach to the recovery process. ${ }^{6}$ The nurse achieved success by inviting Reshma to be part of the process of diffusing the crisis and helping her understand the reasons for her actions. As demonstrated here, open dialogue is only successful if the environment is perceived as 'safe', a condition the nurse established by asking others to leave, thereby providing Reshma the space in which to make her own decisions.

Reshma's experience with this particular nurse is consistent with a framework for consent to medical treatment that upholds the human rights obligations under the CRPD (Article 25(d) requires healthcare professionals to provide care on the basis of 'free and informed consent'). Such a framework requires that consenting parties must have the freedom to negotiate and the freedom to refuse in the context of medical treatment. The process of obtaining valid consent requires active communication between the parties, and the individual who proposes to administer the treatment must provide all the necessary information about the treatment in a manner that is accessible to the patient - this includes offering a range of meaningful choices.

In Reshma's story, the nurse asked Reshma for her consent (and left open the possibility of refusal) before administrating a sedative and provided information about how the treatment would benefit her. The nurse communicated with Reshma in a clear, calm and truthful manner, which was accessible to Reshma in her agitated state. The nurse's course of action provided Reshma the freedom to negotiate as a request for consent implies the right for refusal and Reshma was also given the option to wait for her family to arrive before making a decision. The nurse waited for an active response from Reshma. As Reshma tells us, the nurse cared with "kindness and compassion" and enabled her "to still feel"... "capable of choice. How else can we translate or show care towards a mind that is running amok?"

Reshma recommends that mental health actors translate the care they provide in a manner that is meaningful and accessible to the individual with the disability. Article 12 of the CRPD creates a State obligation to provide mechanisms of support to persons with disabilities while General Comment No. 1 specifies that the types of support will differ based on individual needs but must always respect the rights, will and preference of the individual (CRPD Committee, 2014, paras. 12-15). As Bach and Kerzner_(2010) remind us, the paradigm of the right to legal capacity under Article 12 includes an inquiry into the supports and 
accommodations required to exercise and maximize legal capacity. Moreover, expressions of an individual's choice and capacity must be understood and interpreted generously. As stated in General Comment No. 1 of the CRPD Committee, the obligation for support also includes using non-traditional communication methods to allow people to convey their will and preferences. The manner in which an individual chooses to communicate cannot be used as a means to assess or deny legal capacity (CRPD Committee, 2014, para 17). Article 12 recognizes that there are different ways in which people communicate and make decisions and General Comment No. 1definitively states that 'perceived or actual deficits in mental capacity [may not] be used as a justification for denying legal capacity' (CRPD Committee, 2014, para. 13). Indeed, in her story, Reshma implores health care workers and others to learn "some autism, some schizophrenia, some depression, or some seizures and then communicate to me and others in those languages and see if they can do it" as a means of challenging and expanding rigid conceptions of capacity.

On July 6, 2017 Reshma and I met to discuss her story. In that conversation she advocated passionately for alternative approaches to treatment for individuals experiencing mental health crises. We noted that in the West, family group conferencing involves a gathering of an individual's family and friends to support that individual in making decisions with the aim of rebuilding harmony within the community. The process is premised on building a partnership between family, community leaders and professionals from state agencies based on open communication with an emphasis on supported decision making and crisis prevention (Santegoeds). Reshma emphasized that Article 19 of the CRPD, the provision that guarantees all individuals the right to choose where to live, including the right to live independently and the right to be included in the community, intersects with Articles 12 and 25 , to create in practice, a right to a circle of support. She explained that she experiences something like this positive circle of support within Indian culture and within her community. Reshma suggests that by embracing a social model of disability, which acknowledges that social determinants can cause disability, and certainly exacerbate its effects and meaning, being supported by an empowering community of people who see her as a legal agent in that community - who accept her - and therefore participate in facilitating her emotional physical and spiritual needs, her capacity is enabled by living in such a community. As examples of those whose supports have facilitated her capacity in this way, Reshma includes: her parents, counsellor, many friends, her partner and psychiatrist, whose approach to her, she said, allowed her to live as a legal entity in the community. 
It is well established that determinants of positive health include adequate housing, education, employment and social inclusion (Canadian Mental Health Association, 2017). Reshma is surrounded by a vast social network of family and friends who accept her and participate in facilitating her emotional, physical, and spiritual needs. The unconditional support she receives from an empowering community enables her inclusion in the community as a legal agent. Reshma's positive experience within a culture (and family dynamic) that support her self-determination highlights the importance of the same values enshrined in the CRPD to provide the support and safeguards necessary to allow individuals to exercise legal capacity and to require states to promote these values in legislation, policy and practice.

\section{Bibliography}

Canadian Mental Health Association (2017). Available at: https://ontario.cmha.ca/documents/what-is-the-fit-between-mental-health-mental-illness-andontarios-approach-to-chronic-disease-prevention-and-management/ [Accessed 17 August 2017].

Committee on the Rights of Persons with Disabilities (2014). General Comment No. 1 Article 12: Equal Recognition Before the Law. Available at: http://www.ohchr.org/EH/HRBodies/CRPD/Pages/GC.aspx [Accessed 5 July 2017].

Convention on the Elimination of All Forms of Discrimination against Women, (adopted and opened for signature 18 December 1979, entered into force 3 September 1981). Available from: www.ohchr.org/Documents/ProfessionalInterest/cedaw.pdf [Accessed 29 October 2017].

Convention on the Rights of Persons with Disabilities (adopted 13 December 2006, opened for signature on 30 March 2007, entered into force 3 May 2008) 2515 UNTSS 3. Available from: http://www.un.org/disabilities/documents/convention/convoptprot-e.pdf [Accessed 5 July 2017].

International Covenant on Economic, Social and Cultural Rights Article 12(1), (adopted and opened for signature 16 December 1966, entered into force 3 January 1976). Available from: www.ohchr.org/Documents/Professionalinterest/cescr.pdf [Accessed 29 October 2017].

Convention on the Rights of the Child, (adopted and opened for signature on 20 November 1989, entered into force 2 September 1990). Available from: www.ohchr.org/EN/Professionalinterest/Pages/CRC.aspx [Accessed 29 October 2017].

Bach, M. and Kerzner, L. (October 2010). A New Paradigm for Protecting Autonomy and the Right to Legal Capacity. Law Commission of Ontario. Available from: http://www.lcocdo.org/disabilities/bach-kerzner.pdf [Accessed 29 October 2017].

Brosnan, L. and Flynn, E. (2017). Freedom to Negotiate: A Proposal Extricating 'Capacity' From 'Consent' International Journal of Law in Context, 13(1), pp. 58-76. [Accessed 1 July 2017]. 
Gaventa, J. (2006). Finding the spaces for change: a power analysis. IDS Bulletin, 37, pp. 2333.

Morrison, A.P., Hutton, P., Shiers, D. and Turkington, D. (2012). "Antipsychotics: is it time to introduce patient choice?" The British Journal of Psychiatry 201.2, pp. 83-84.

Open Dialogue UK (2017). Available from: http://opendialogueapproach.co.uk/ [Accessed 17 August 2017].

Santegoeds, J. Respecting persons and dealing with diversity in psychosocial crisis situations - Experience-based development of an alternative to forced psychiatric interventions. Available from: http://www.mindrights.org/Preliminary\%20article_experience\%20based\%20development $\% 2$ 0of\%20the\%20Eindhoven\%20Model.pdf [Accessed 29 October 2017].

\footnotetext{
${ }^{1}$ Levera and Gabapentin are anti-seizure medications.

${ }^{2}$ Pranayama is a yogic breathing exercise that consists of different breathing techniques and impacts food choices.

${ }^{3}$ My neurologist and Dr. X played an important role in my care and management though I never liked their back and forth inquiry of my schizophrenia.

${ }^{4}$ Frisium is a medicine under the class of benzodiazepines used in the treatment for seizures.

${ }^{5}$ India has subsequently enacted mental health legislation which guarantees persons with disabilities the right to equality and non-discrimination in the context of medical treatment. Mental Health Care Act, 2017.

${ }^{6}$ Open dialogue as a formal practice was developed by Jaakko Seikkula and Marku Suttela. Although it is a practice used in the western context, the nurse who engages with Reshma in India intuitively follows many of the same principles and practices associated with this method in her interactions with Reshma. What is regarded as alternative in one culture may be normative in another. For further discussion of open dialogue see: (Open Dialogue, 2017) http://opendialogueapproach.co.uk/
} 